Mr. Ibrahim KABIL

Tuzla

E-mail: ibrahim.kabil@hotmail.com

Stručni rad/Professional article

UDK/UDC: 94:332:325(497.6)"1945/1948" Šabotić I. (049.3)

DOI: https://doi.org/10.52259/historijskipogledi.2021.4.6.364

\title{
Izet Šabotić, TVRDA KORA I KRVAVE BRAZDE: Agrarna reforma i kolonizacija u Bosni i Hercegovini od 1945. do 1948. godine, Centar za istraživanje moderne i savremene historije Tuzla, Tuzla 2021, 369 str.
}

U izdanju Centra za istraživanje moderne i savremene historije Tuzla iz štampe je izašla publikacija prof. dr. Izeta Šabotića: TVRDA KORA I KRVAVE BRAZDE: Agrarna reforma i kolonizacija u Bosni i Hercegovini od 1945. do 1948. godine.

Tema istraživanja čije rezultate sadrži ova publikacija je „socijalistička rekonstrukcija" poljoprivrede i sela poslije Drugog svjetskog rata u Bosni i Hercegovini, u „prelaznom periodu”. Rezultati predstavljeni u ovom radu su sinteza istraživanja arhivskih izvora, tekstova savremenika koji su presudno uticali na formiranje agrarne politike, zatim dnevne i stručne štampe, kao i periodike, kako specijalizovane, poljoprivredne (časopisi posvećeni poljoprivredi i zadrugarstvu) tako i „direktivne" (časopisi ministarstava, državnih organa, partijski časopisi). U središtu istraživanja bio je odnos države prema seljaštvu i seljačkom zemljišnom posjedu, ali je ta tema stavljena u širi kontekst ukupne agrarne politike jugoslovenske države u istraživanom periodu. Poseban naglasak na seljačkom posjedu, odnosno stavljanje ove teme u fokus istraživačkog interesovanja zapravo je samo odraz činjenice da je od 1945. do 1948. upravo rješavanje pitanja statusa seljačke zemljišne svojine bilo glavni izazov za Partiju državu na čijem je čelu Partija bila. Traganje za odgovarajućom formom rješavanja ovog pitanja prouzrokovalo je turbulencije u posjedovnoj strukturi. To je neminovno stvaralo probleme u nastojanjima države da se podigne poljoprivredna proizvodnja, koja je i dalje počivala, u najvećoj mjeri, na individualnim proizvođačima, o čijoj se sudbini rješavalo tokom čitavog perioda.

Glavni procesi koji su obilježili agrarnu politiku u hronološkom okviru koji pokriva ovaj rad su agrarna reforma i kolonizacija, državni otkup poljoprivrednih proizvoda, razvoj socijalističkog zadrugarstva i seljačkih radnih zadruga. Svi ovi procesi duboko su se ticali pitanja seljačkog vlasništva nad zemljom, vrlo daleko postavljajući granice prava države u odnosu na seljaštvo. 
Knjiga Tvrda kora i krvave brazde: Agrarna reforma i kolonizacija u Bosni i Hercegovini od 1945. do 1948. godine sadrži 369 strana, a sastoji se od četiri poglavlja.

Prvo poglavlje, Agrarno-posjedovni odnosi u Bosni i Hercegovini do 1945. godine, (21-49) u dijelovima donosi historijat rješavanja agrarnog pitanja u Bosni i Hercegovini za vrijeme osmanske uprave i austrougarske okupacije do 1918. godine, rezultate i posljedice agrarne reforme u vrijeme Kraljevine SHS, odnosno Kraljevine Jugoslavije od 1918. do 1941. godine $\mathrm{i}$ agrarne odnose $\mathrm{u}$ Bosni i Hercegovine za vrijeme Drugog svjetskog rata (1941-1945).

Agrarni odnosi koji su u Bosni i Hercegovini zatečeni poslije Prvog svjetskog rata rezultat su viševjekovne osmanske vladavine kao i četrdesetogodišnje austrougarske okupacije. Ti odnosi su se krajem 18. i u prvoj polovini 19. vijeka, uporedo sa slabljenjem Osmanskog Carstva, često mijenjali, da bi se konačno Saferskom naredbom od 1859. godine zakonski regulisali. Tom naredbom ozakonjeno je sve ono što je stvoreno dugim procesom čiflučenja.

Austrougarska vlast

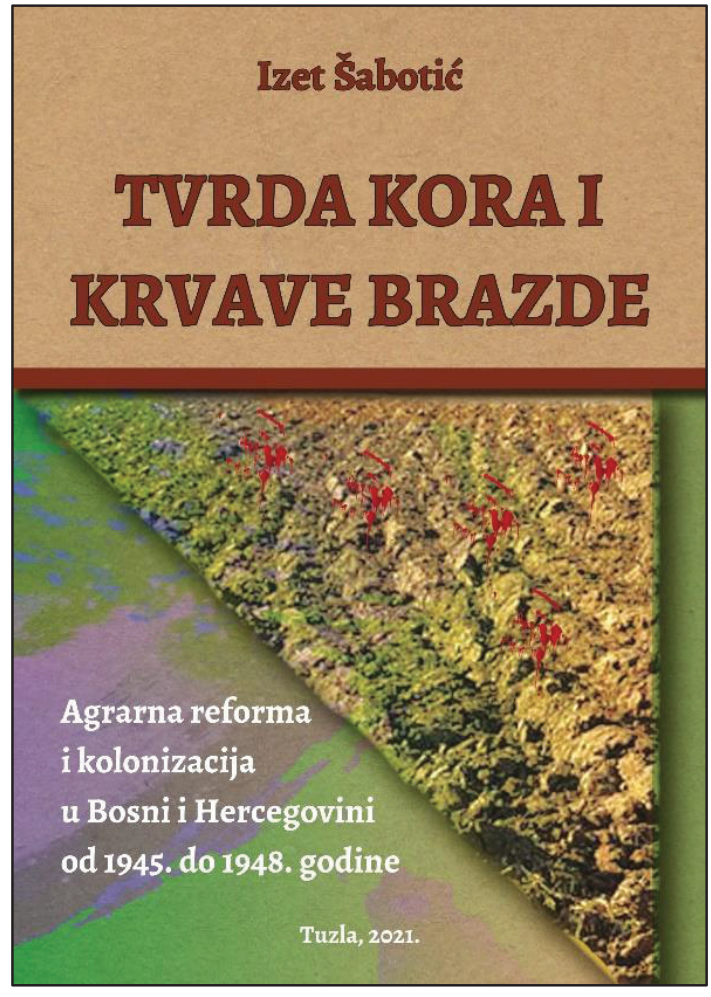

po dolasku u Bosnu i Hercegovinu nije pristupila ukidanju feudalnih agrarnih odnosa uglavnom iz političkih razloga. Rješavanjem ovog pitanja, ona se morala zamjeriti feudalcima, a onda i čitavom muslimanskom stanovništvu, koje je bilo pod njihovim uticajem. Ona to nije željela.

Završetak Prvog svjetskog rata, raspad Austro-Ugarske, ulazak srpske vojske u Bosnu i Hercegovinu, a zatim i stvaranje prve jugoslovenske države, seljaci-kmetovi u Bosni i Hercegovini su sa oduševljenjem dočekali, smatrajući da je pored nacionalnog automatski riješeno i agrarno pitanje. U novembru i decembru 1918. na bosanskohercegovačkim selima imamo revolucionarna situaciju. Mnoga imanja zemljoposjednika - aga i begova - opljačkana su i zapaljena, a izvjestan broj aga i begova i njihove posluge - je ubijen. To paljenje čardaka, samovoljno prisvajanje kmetske i beglučke zemlje, protjerivanje aga i begova sa sela - tipični su atributi agrarne revolucije. I ona je, stvarno, tih dana u 
Bosni bila u punom jeku, ali će ostati nedovršena i brzo će se sabiti u zakonske okvire.

Nasilje se sa agrarnog prenijelo na druga polja, pri čemu je bošnjačka imovina doša pod udar. Veoma brzo je donesen čitav set propisa, koji su podrazumijevali uzurpaciju čifčijskih selišta i begluka. Tome je posebno doprinijela Uredba o upisu vlasništva bivših kmetskih selišta u zemljišnim knjigama u Bosni i Hercegovini donesena 1919. godine. Agrarnom reformom, provedenom od 1919. do 1941. godine u Bosni i Hercegovini je oduzeto 1.175.305 ha zemlje, što je potpuno osiromašilo, ponajviše bosanskohercegovačke age i begove, kao i druge veleposjednike. Provođenje agrarne reforme imalo je za cilj ne samo socijalno-ekonomske promjene, već se očigledno radilo o nacionalno-etničkim ciljevima usmjerenim ka oduzimanju zemlje od predstavnika jednog naroda, u ovom slučaju Bošnjaka, i davanju iste seljacima drugog naroda, u ovom slučaju Srbima. Tako da je agrarna reforma provođena od 1919. do 1941. godine bila pogubna za bošnjačke veleposjednike age i begove, koji su ovim procesom potpuno ekonomski osiromašili.

Početkom Drugog svjetskog rata vlasti tzv. NDH su donošenjem propisa u oblasti agrarner problematike imali za cilj prodobijanje bivših bosanskohercegovačkih zemljoposjednika te je donijela zaključak da se međuratnom agrarnom reformom oduzeta zemlja ima vratiti bosanskim zemljoposjednicima. Međutim, zbog općih kretanja i razvoja NOP-a do realizacije navedenih zaključaka nikada nije došlo.

Uslovi, okolnosti, pravne i organizacione osnove za izvođenje agrarne reforme $i$ kolonizacije (51-80) naslov je drugog poglavlja $\mathrm{u}$ kojem autor istražuje prilike na selu nakon Drugog svjetskog rata, političke pripreme za provođenje agrarne reforme i kolonizacije, zatim donošenje Zakona o agrarnoj reformi i kolonizaciji i drugih pratećih propisa. Autor također opisuje i koji su organi i ustanove bili zaduženi za provođenje agrarne reforme i kolonizacije.

Nakon Drugog svjetskog rata prilike na selu u Bosni i Hercegovini bile su veoma složene i teške. Oko 83\% stanovništva činila je seoska populacija. Selo je u toku Drugog svjetskog rata imalo velike gubitke. Stočni fond je smanjen za $70 \%$. Slično stanje je bilo u voćarstvu, povrtlarstvu i vinogradarstvu, a oko 33\% stambenih i privrednih objekata na bosanskohercegovačkom selu je stradalo, kao i veliki broj mlade seoske populacije.

Nastanak konkurentskog povlašćenog državnog i zadružnog sektora poljoprivrede, uklapanje individualnih seljaka u plansku privredu, nastojanje države da intervencijom modernizuje obradu zemlje i poljoprivrednu proizvodnju, masovne akcije oranja, sjetve, borbe protiv štetočina, uvođenja naprednih agrotehničkih mjera, progresivno oporezivanje dohotka od gazdinstava bili su važne karakteristike agrarne politike koja je trebalo istovremeno i da podigne ukupni nivo života na selu, ali i da seljake uvjeri u prednosti socijalističkih krupnih gazdinstava. Cilj koji je vlast postavila bio je protivrječan: seljak je trebalo da živi bolje nego ranije, ali ne bolje od industrijskog radnika i ne toliko dobro da bi bio ravnodušan prema socijalističkoj 
rekonstrukciji poljoprivrede ili čak protivan izgradnji socijalizma na selu, u kojem je trebalo da vidi svoju perspektivu.

Otpor provođenju agrarne reforme posebno je bio izražen kod veleposjedničkih kategorija i vjerskih zajednica na cijelom prostoru Bosne i Hercegovine. Da bi se ušlo u process provođenja agrarne reforme i kolonizacije, neophodno je bilo izvršiti sve potrebne pripreme, vezane za osiguranje zakonodavno-pravnih, ali i drugih uslova, poput osiguranja smještaja, stoke, mašina, odjeće i drugog materijala. Dana 23. augusta 1945. Privremena Narodna skupština donijela je Zakon o agrarnoj reformi i kolonizaciji, koji se, prema članu 1. Zakona, trebao provesti prema načelu ,zemlja pripada onima koji je obrađuju“.

Zakonom je određeno da se zemljišni fond za reformu i kolonizaciju treba stvoriti oduzimanjem od tadašnjih vlasnika i prelaskom u ruke države poljoprivrednih dobara - velikih posjeda, tj. takvih poljoprivrednih i šumskih dobara čija ukupna površina prelazi 45 hektara ili od 25 do 35 hektara obradive zemlje (oranice, livade, voćnjaci i vinogradi), ako se iskorištavaju putem zakupa ili najamne radne snage; zemljišnih posjeda u vlasništvu banaka, poduzeća, dioničkih društava $\mathrm{i}$ drugih privatnopravnih osoba i drugih pravnih osoba određenih zakonom, osim onih dijelova koji će se vlasnicima ostaviti za industrijske, građevinske, znanstvene, kulturne i druge društveno korisne svrhe; zemljišnih posjeda crkava, samostana, vjerskih ustanova i svih vrsta zaklada svjetovnih i vjerskih vakufa; viška obradive zemlje zemljoradničkih posjeda iznad zakonom određenog maksimuma i dr.

Ovim Zakonom crkveno vlasništvo nad zemljom ograničeno je na 10 hektara, ali se za vjerske ustanove veće važnosti ili veće historijske vrijednosti predvidjelo ostavljanje posjeda do 30 hektara obradive zemlje i do 30 hektara šume (član 8). Maksimum vlasništva zemljoradničkog posjeda zemljoradnika koji ga obrađuje sa svojom porodicom nije mogao biti veći od 35 hektara obradive zemlje, s tim da je određivanje maksimuma određivano $\mathrm{s}$ obzirom na broj članova porodice (zadruge), kvalitete zemljišta i vrste kulture.

Pravo prvenstva u dodjeljivanju zemlje imali su zemljoradnici bez zemlje, ili s nedovoljno zemlje, koji su bili borci partizanskih jedinica. Savezni Zakon dao je u nadležnost republičkim ministarstvima poljoprivrede $u$ provođenju agrarne reforme i kolonizacije. Sve republike su donijele vlastito zakonodavstvo o agrarnoj reformi i kolonizaciji, i sve republike su imale svoje specifikume u provođenju agrarne reforme i kolonizacije. U Bosni i Hercegovini su na udaru agrarne reforme i kolonizacije bili preostali veliki zemljišni posjedi, posjedi narodnih neprijatelja te posjedi vjerskih zajednica.

Posljedice provedene agrarne reforme i kolonizacije u Bosni i Hercegovini bile su obimne i dalekosežne. Težnja velikog broja siromašnog seljaštva, da konačno dobije zemlju u vlasništvo nije ostvarena u skladu sa proklamovanom politikom komunističke vlasti, jer je veliki broj seoskog stanovništva ostao van domašaja agrarne reforme i kolonizacije. Kao glavni rezultat agrarne reforme i kolonizacije nameće se promjena vlasničkih odnosa, koja se više ogleda kroz državni i nacionalno-etnički, nego kroz ekonomsko- 
socijalni rezultat, što je bio nastavak započetih procesa u agraru, agrarnom reformom provedenom od 1919. do 1941. godine.

Provođenje kolonizacije iz Bosne i Hercegovine u Vojvodinu (81-126) naslov je trećeg poglavlja. Autor se bavi planovima i tempom provođenja kolonizacije te njenim rezultatima. Glavni val kolonizacije u novoj Jugoslaviji bio je usmjeren prema Vojvodini. Naseljavali su ga prvenstveno borci NOB -a. Provođenjem kolonizacije u Vojvodini ostvarile su se vjekovne težnje srpskog nacionalnog korpusa da se na jedan radikalan način izmjene posjedovno-agrarni odnosi na ovom prostoru u njihovu korist. Osnova za provođenje kolonizacije bila je konfiskacija zemljišnih posjeda Nijemaca, kojima je oduzeto 97.490 posjeda sa 637.939 ha zemlje. Na te zemljišne posjede planirano je naseljavanje 45.000 kolonističkih porodica pretežno iz Bosne i Hercegovine, Hrvatske i Crne Gore. Pretežno se radilo o srpskom nacionalnom kolonističkom elementu. Najveću kolonističku kvotu od 12.000 porodica imala je Bosna i Hercegovina. Proces kolonizacije uz određene organizacione poteškoće odvijao se po planu. Kolonisti su se naseljavali počev od septembra 1945. godine u unaprijed utvrđena područja. Prema raspoloživim podacima, bosanskohercegovačke kolonističke porodice naselile su ukupno 122 naselja u 28 srezova u Banatu i Bačkoj. Iz Bosne i Hercegovine u Vojvodinu do kraja 1948. godine, naselilo se ukupno 13.200 porodica sa 83.091 članom. Najveći broj kolonista, koji su se naselili u Vojvodinu bili su s područja Bosanske Krajne 24,4\% i Hercegovine, oko 12\%. Riječ je o područjima koja su pretežno bila naseljena srpskim nacionalnim korpusom. Prema raspoloživim podacima oko 98\% kolonističke populacije naseljene u Vojvodini činili su Srbi, dok je broj Hrvata i Bošnjaka bio neznatan. Stoga se može zaključiti da je jedan od ciljeva kolonizacije u Vojvodinu bio etničko-nacionalnog karaktera, jer je nakon provedene kolonizacije Vojvodina postala srpski nacionalno-etnički prostor.

Istovremeno, procesom kolonizacije isti je brojčano znatno oslabljen $\mathrm{u}$ Bosni i Hercegovini, sa preseljenjem više od 78.000 lica, što je imalo određene demografske refleksije. Naime, srpski nacionalni element je procesom kolonizacije u značajnoj mjeri oslabio u Bosni i Hercegovini, što je uticalo da Bošnjaci uz povoljan natalitet postanu najbrojniji narod. No, napušteni teritorijalni prostor zahvaljujući političkim stavovima ostao je i dalje dominantno srpski etnički prostor, što je imlo odraza na dalja kretanja u Bosni i Hercegovini.

Četvrto, posljednje, poglavlje Provođenje agrarne reforme i unutrašnje kolonizacije u Bosni $i$ Hercegovini (127-318) bavi se širokim spektrom rješavanja agrarne problematike. Provođenje i rezultati agrarne reforme i unutrašnje kolonizacije su zavisili, ne samo od ukupnog obima zemljišnog fonda, nego i od njegove strukture, odnosno veličine obradivog zemljišta. Za dodjelu zemlje iz zemljišnog fonda, od strane seoske populacije postojao veliki interes. Toga su bili svjesni partijski i državni, i organi zaduženi za provođenje agrarne reforme i kolonizacije, što je podrazumijevalo odstupanje od načela podjele zemlje individualnim zemljoradnicima u korist državnog agrarnog sektora, što je 
bilo u skladu sa zagovaranom politikom u oblasti agrara na saveznom nivou, vezanom za realizaciju Petogodišnjeg plana u oblasti poljoprivrede.

U procesu obrazovanja zemljišnog fonda u Bosni i Hercegovini, najobimniji su bili posjedi ostavljeni od stane kolonista odseljenih u Vojvodinu. Ovi zemljišni posjedi bili su najrasprostraniji na području Posavine i Semberije i činili su veliki dio obradivih zemljišnih površina pogodnih za razvoj poljoprivredne proizvodnje. Stoga su i imali značajnu ulogu u obrazovanju zemljišnog fonda i provođenju agrarne reforme i kolonizacije u Bosni i Hercegovini.

Uspostavom nove agrarno posjedovne strukture, Bosna i Hercegovina je i dalje ostala zemlja sitnog seljačkog posjeda, čime nije riješeno pitanje agrarne prenaseljenosti. Uspostavljena je dominacija sitnog i srednjeg zemljišnog posjeda, što je imalo negativne posljedice na razvoj poljoprivrede, koja je nazadovala nakon provođenja agrarne reforme i kolonizacije.

Ovom reformom je dokrajčeno postojanje velikih zemljišnih posjeda. Bosanskohercegovački begovi i age, koji su, uglavnom, bili muslimani, najvećim dijelom su već osiromašeni reformama koje je provodila austrougarska uprava, a posebno nakon 1918. godine, kada su im, osim znatnog dijela begluka, oduzeta sva takozvana kmetska selišta, odnosno oni njihovi posjedi na kojima su obrađivači imali takozvano kmetsko pravo. Na taj su način poslije Prvog svjetskog rata većinom seljaci Srbi postajali vlasnici zemljišnih kompleksa koje su dotada obrađivali, iako su ti posjedi bili vlasništvo muslimanskih posjednika

Agrarna politika jugoslovenskih vlasti od 1945-1948. bila je sveobuhvatan projekat koji je trebalo da iz temelja preobrati poljoprivredu u Jugoslaviji, pa samim time i u Bosni i Hercegovini. Međutim, u čitavom istraživanom periodu zapravo se tragalo za odgovarajućom formulom „socijalističke rekonstrukcije poljoprivrede”, prije svega u kontekstu rješavanja sudbine sitnog i srednjeg seljačkog posjeda. Tu formulu je trebalo pronaći uz istovremeno izbjegavanje opasnosti od pada poljoprivredne proizvodnje usljed suviše naglih strukturnih promjena. Činjenica da jugoslovenski komunisti dugo nisu uspjeli da pronađu adekvatne odgovore na izazove sa kojima su se suočavali ipak je ostavljala posljedice na fizičkom obimu i kvalitetu poljoprivredne proizvodnje. Ostajući vjerni marksističkim načelima, jugoslovenski komunisti su prošli dugačak put od opreznog zalaganja za stvaranje seljačkih radnih zadruga, preko intenziviranja kolektivizacije, do njenog potpunog odbacivanja 1953. godine, koje nije bilo samo pragmatično napuštanje neuspješnog projekta već suštinski preokret u razumjevanju odnosa na selu, ciljeva socijalizma i suštine klasne borbe.

Agrarna politika od 1945. do 1948. bila je izuzetno dinamična, institucije za njeno sprovođenje doživljavale su duboke organizacione promjene, sve njene mjere su imale kompleksnu unutrašnju evoluciju, nijedna organizaciona forma nije se ustalila. Međutim, mjere agrarne politike nisu se uvijek „na terenu“ sprovodile na način na koji su bile koncipirane od strane partijskih i državnih 
rukovodilaca, a njihov sadržaj se mijenjao suviše brzo, pod uticajem konkretnog iskustva, koje je zatim teorijski uobličavano.

Knjiga obiluje brojnim podacima i tabelama koje nam donose uvid u dio zbivanja na uzavrelom bosanskohercegovačkom tlu neposredno nakon Drugog svjetskog rata. Na kraju se nalazi spisak korištenih izvora. Autor je svoja istraživanja vršio u najvažnijim arhivima na ovu temu, uključujući arhive u Bosni i Hercegovini i Arhiv Jugoslavije u Beogradu. Ovaj spisak omogućiće budućim istraživačima da lakše dođu do izvora i literature vezane za izučavanje tema vezanih za agrarno pitanje u Bosni i Hercegovini kao i proces kolonizacije u Vojvodinu. 